Vol.5 No.2

\title{
PENCATATAN AKUNTANSI PADA USAHA MIKRO KECIL DAN MENENGAH (STUDI PADA UMKM MR. PELANGI SEMARANG)
}

\author{
Rosita Vega Savitri, Saifudin
}

Universitas Semarang

A R T I C LE IN FO

Keywords : accounting
records, UMKM

Kata Kunci : Pencatatan

Akuntansi, UMKM

Corresponding author :

Rosita Vega Savitri

rositavegas90@gmail.com

\begin{abstract}
Business Sector, which is incorporated in the scale of UMKM has a very essential role for the economic condition of Indonesia, as evidenced by the increase of Gross Domestic Product (GDP) from year to year. With the UMKM job opportunities are increasing, thus reducing the unemployment rate. This research was conducted to find out how the practice of recording accounting on UMKM's and how the perception owner of UMKM to accounting records. The sample in this research use one kind of business that is UMKM Mr. Pelangi in Semarang. This research uses interactive model data analysis technique with primary data source and qualitative method.The results of this study indicate that not yet the maximum accounting recording at UMKM Mr. Pelangi Semarang because of the perception of the owner who think that accounting is a complicated matter and if the owner has experts in the field of accounting it will increase the cost of salary in the business.
\end{abstract}

Abstrak: Sektor bisnis, yang dimasukkan dalam skala UMKM memiliki peran yang sangat penting untuk kondisi ekonomi Indonesia, sebagaimana dibuktikan oleh peningkatan dari produk domestik bruto (PDB) dari tahun ke tahun. Dengan UKM peluang kerja meningkat, sehingga mengurangi tingkat pengangguran. Penelitian ini dilakukan untuk mengetahui bagaimana praktek pencatatan akuntansi pada UMKM dan bagaimana persepsi pemilik UMKM terhadap pencatatan akuntansi. Sampel dalam penelitian ini menggunakan salah satu jenis bisnis yang UMKM MR.Pelangi di Semarang. Penelitian ini menggunakan teknik analisis data model interaktif dengan sumber data primer dan kualitatif metode. Hasil studi ini menunjukkan bahwa pencatatan akuntansi belum maksimum di UMKM MR.Pelangi Semarang karena persepsi dari pemilik yang berpikir bahwa akuntansi adalah masalah rumit dan jika pemilik memiliki ahli di bidang Akuntansi itu akan meningkatkan biaya gaji dalam bisnis. 


\section{PENDAHULUAN}

\section{Latar Belakang}

Di era globalisasi, berbagai jenis usaha dituntut untuk lebih maju dan dapat bertahan dalam menjalankan jenis usahanya. Indonesia sebagai negara berkembang, lebih menitikberatkan pembangunan dan pertumbuhan ekonomi ke arah yang lebih baik. Proses ini berpengaruh langsung kepada berbagai bentuk usaha di Indonesia. Seiring dengan berjalannya waktu, di Indonesia terbentuk berbagai macam jenis usaha, baik usaha berskala kecil maupun usaha berskala besar. Salah satu jenis usaha di Indonesia adalah Usaha Mikro Kecil dan Menengah (UMKM). Sektor Usaha yang tergabung dalam skala Usaha Mikro Kecil dan Menengah (UMKM) ini mempunyai peranan yang sangat esensial bagi kondisi perekonomian negara Indonesia, terbukti dengan adanya peningkatan Produk Domestik Bruto (PDB) dari tahun ke tahun. Menurut data kementrian Koperasi dan Usaha Mikro Kecil dan Menengah, pada tahun 2013 tercatat kontribusi UMKM terhadap PDB Indonesia pada triwulan ke III- 2012 tumbuh sebesar Rp 135.602.200 juta atau meningkat sebesar 9,90 persen dari tahun 2011.

Besarnya kontribusi dari sumbangan PDB UMKM, akan berdampak pada penyerapan jumlah tenaga kerja dari sektor UMKM yaitu hingga tahun 2013 telah tumbuh sebesar 114.114.082 juta atau 6,03 persen dari tahun 2012 (www.depkop.go.id dalam Andriano,dkk, 2017). Hal ini menggambarkan besarnya potensi yang dapat dikembangkan dan ditingkatkan bagi sektor UMKM untuk dapat berkontribusi bagi negeri ini. Melihat kontribusi yang begitu besar yang diberikan oleh UMKM, maka diperlukan perhatian lebih dari pemerintah untuk mengembangkan sekaligus mempertahankan potensi Usaha Mikro Kecil dan Menengah (UMKM) di Indonesia. Hal ini terbukti dengan bertahannya UMKM terhadap krisis moneter yang terjadi tahun 1998 menjadi alasan utama mengapa pemerintah harus menaruh perhatian yang besar. Sejak krisis yang terjadi pada tahun 1998, hampir 80 persen usaha besar mengalami kebangkrutan dan banyak melakukan PHK. UMKM sangat berperan dalam mengurangi tingkat pengangguran. Oleh karena itu, keberhasilaan UMKM mampu meningkatkan perekonomian Indonesia karena kegiatan operasional UMKM dapat mandiri dan tidak menanggung beban besar akibat krisis tersebut (Arifin,dkk, 2012). Dengan adanya UMKM (Usaha Mikro Kecil dan Menengah) peluang kerja semakin bertambah, sehingga dapat mengurangi angka pengangguran.

Peran UMKM selama ini diakui berbagai pihak cukup besar dalam perekonomian nasional. Beberapa peran strategis UMKM menurut Bank Indonesia (2013) dalam Supriono,dkk (2017) antara lain :

1. Jumlahnya yang besar dan terdapat dalam setiap sektor ekonomi

2. Menyerap banyak tenaga kerja dan setiap investasi menciptakan lebih banyak kesempatan kerja

3. Memilik kemampuan untuk memanfaatkan bahan lokal dan menghasilkan barang dan jasa yang dibutuhkan masyarakat luas dengan harga terjangkau

UMKM merupakan usaha yang memiliki pemilik sekaligus pengelola yang sama, modal disediakan oleh seorang pemilik atau sekelompok kecil pemilik modal. Sasaran pasar UMKM umumnya lokal, meskipun ada yang mengekspor produknya ke luar negeri dan memiliki jumlah karyawan, total asset, dan sarana-prasarana yang sedikit. UMKM terdiri dari berbagai jenis usaha, seperti perusahaan manufaktur, perusahaan dagang, dan perusahaan jasa (Wuwungan,2015). Salah satu tantangan utama yang dihadapi oleh wirausahawan UMKM adalah terkait dengan pengelolaan dana. Pengelolaan dana yang baik merupakan faktor kunci yang dapat menyebabkan keberhasilan atau kegagalan UMKM. Metode praktis dan manjur dalam pengelolaan dana pada UMKM adalah dengan menerapkan akuntansi dengan baik. Dengan demikian, akuntansi menjadikan UMKM dapat memperoleh berbagai informasi keuangan dalam menjalankan usahanya (Arifin,dkk,2012). Pencatatan akuntansi harus sesuai dengan setiap transaksi yang terjadi dan berdasarkan standar akuntansi yang berlaku. Standar akuntansi mempunyai perlakuan akuntansi mulai pengakuan, pengukuran, penyajian maupun pengungkapan, dan tentunya dapat menjadi dasar untuk menyusun laporan keuangan yang andal (Andrianto,dkk,2017). Namun dalam pelaksanaanya pembukuan tersebut merupakan hal yang sulit bagi pengusaha UMKM karena keterbatasan pengetahuan terhadap ilmu akuntansi, rumitnya proses akutansi, dan anggapan bahwa laporan keuangan bukanlah hal yang penting bagi pengusaha UMKM.

Bertolak belakang dengan pentingnya pencatatan akuntansi, pada kenyataannya masih banyak pelaku UMKM yang belum menggunakan informasi akuntansi secara maksimal pada usahanya atau mungkin belum menerapkannya sama sekali, begitu juga dengan pola pikir pelaku UMKM yang beranggapan apabila dalam usahanya menerapkan akuntansi hanya akan menambah rumit pekerjaan. Fenomena seperti ini tentunya sering ditemukan pada UMKM. karena belum adanya kesadaran dari para pelaku UMKM tentang pentingnya pencatatan 118 
akuntansi pada usahanya. Seharusnya para pelaku UMKM dapat memahami manfaat dari pencatatan akuntansi, hal ini karena aspek penting dari pengelolaan suatu usaha adalah keuangan, maka apabila pengelolaan keuangan pada suatu usaha amburadul atau tidak terkelola dengan baik dapat dipastikan usaha tersebut akan mengalami gejolak dan tidak jarang hingga mengalami gulung tikar.

Kota Semarang merupakan ibukota Jawa Tengah dimana potensi dari UMKM harus dikembangkan dan perlu mendapatkan perhatian khusus dari pemerintah. Pemerintah telah menetapkan standar akuntansi keuangan untuk UMKM yang bertujuan untuk memberikan kemudahan bagi entitas skala kecil dan menengah serta bermanfaat untuk mendapatkan dana (misalnya dari bank) untuk pengembangan usaha melalui informasi yang handal dalam penyajian laporan keuangan tersebut dan sebagai pemberi informasi dalam pengambilan keputusan. Informasi akuntansi keuangan mempunyai peran yang penting dalam pencapaian keberhasilan usaha termasuk bagi usaha kecil (Megginson,et.al,2000 dalam Ulfah,2017). Sektor UMKM yang berkembang di Kota Semarang sangat beraneka ragam, salah satunya industri konveksi seperti keset (alas kaki).

Penelitian ini mengambil obyek pada Industri keset karakter dengan kain perca sebagai bahan baku yang ada di Kota Semarang. Usaha ini merupakan usaha rumahan yang pemasarannya cukup luas di seluruh Indonesia, dan usaha ini juga berpotensi merambah pasar internasional dengan mengekspornya ke luar negeri. Usaha ini memberikan manfaat yang besar di bidang perindustrian karena memanfaatkan limbah yang biasanya dibuang atau hanya menjadi sampah. Usaha ini memanfaatkan kain perca dari limbah pabrik konveksi. Karena UMKM sukses adalah UMKM yang mampu memanfaatkan sumberdaya tersedia terutama yang bernilai ekonomi rendah termasuk limbah menjadi barang - barang yang bernilai ekonomi tinggi. Keberhasilan UMKM sukses ternyata tidak hanya karena keahlian yang dimiliki, tetapi juga dipengaruhi oleh banyak faktor antara lain : a) jiwa kewirausahaan dan kreatifitas individual yang melahirkan inovasi; b) ketersediaan bahan baku, iklim usaha, dukungan finansial, ketersediaan informasi baik pengetahuan dan teknologi, ketersediaan pasar dan dukungan infrastruktur (Wuwungan,2015).

Dengan skala usaha dibidang ini, mayoritas bisa menghasilkan omzet yang menjanjikan dan jika usaha ini ditekuni maka usaha ini semakin lama akan semakin menigkat dan berkembang. Prospek pengembangan usaha ini pun cukup baik, karena hampir semua aktifitas dalam rumah tangga membutuhkan keset sebagai alas kaki. Apalagi keset karakter ini memiliki bentuk yang unik sehingga multifungsi. Industri rumahan keset karakter umumnya merupakan usaha perorangan berskala kecil sampai menengah. Dan dilihat dari usaha pemanfaatan kain perca yang skala usahanya masih berskala mikro dan kecil, diperlukan pencatatan akuntansi yang sesuai acuan/pedoman akuntansi yang berlaku. Dengan pencatatan akuntansi yang memadai dan handal maka pelaku usaha akan dapat menyusun laporan keuangan yang mencerminkan kondisi keuangan pada periode tersebut, sehingga akan lebih mudah untuk mengambil langkah strategis dalam pengembangan usahanya.

Berdasarkan uraian latar belakang diatas, maka peneliti ingin melakukan penelitian yang berjudul " PENCATATAN AKUNTANSI PADA USAHA MIKRO, KECIL, DAN MENENGAH (UMKM) ( Studi pada UMKM Keset Karakter Mr. Pelangi Semarang )"

\section{Tujuan Penelitian}

Berdasarkan rumusan masalah, maka tujuan dari penelitian ini adalah :

1. Untuk mengetahui bagaimana praktik pencatatan akuntansi pada UMKM.

2. Untuk mengetahui persepsi pelaku UMKM terhadap pencatatan akuntansi.

\section{TINJAUAN PUSTAKA}

\section{Teory Agensi (Agency Theory)}

Dari sudut pandang teori agensi, prinsipal (pemilik atau top manajemen) membawahi agen (karyawan atau manajer lebih rendah) untuk melaksanakan kinerja yang efisien.Teori ini mengasumsikan bahwa kinerja organisasi ditentukan oleh usaha dan pengaruh kondisi lingkungan.Teori ini secara umum mengasumsikan bahwa prinsipal adalah risk-neutral dan agen adalah risk and effort averse. Agen dan prinsipal diasumsikan dimotivasi oleh kepentingannya sendiri dan sering kepentingan antara keduanya berbenturan (Purhantara,2010). 


\section{Akuntansi}

Banyak sekali pihak yang membutuhkan informasi keuangan untuk digunakan dalam mengambil keputusan yang bersifat ekonomis.Makin majunya peradaban dan kegiatan ekonomi, makin penting pula informasi tersebut.Informasi keuangan salah satunya dihasilkan melalui akuntansi. Pada era informasi, peran akuntansi sebagai alat bantu dalam pengambilan keputusan ekonomi dan keuangan dalam suatu usaha makin dibutuhkan. Akuntansi sebagai suatu sistem pengukuran daan pencatatan dalam pengelolaan sumber-sumber ekonomi (kekayaan) yang akan menghasilkan imformasi keuangan. Informasi keuangan perusahaan tersebut ditujukan kepada berbagai pihak yang berkepentingan dengan perusahaan (stakeholder) guna membantu mereka dalam pengambilan keputusan yang terkait dengan perusahaan tersebut.Oleh karena itu, akuntansi sering disebut sebagai bahasa perusahaan (business language) atau bahasa pengambilan keputusan (financial decesion of language).

\section{Laporan Keuangan}

Laporan keuangan ditujukan kepada berbagai pihak yang berkepentingan dalam suatu usaha.Hal tersebut ditujukan untuk membantu mereka dalam pengambilan keputusan ekonomi yang berkaitan dengan usaha.Berdasarkan laporan keuangan ini, pihak pemakai dapat menilai kondisi keuangan usaha, keberhasilan usaha dalam mencapai tujuan, dan prospek usaha pada masa mendatang. Laporan keuangan merupakan salah satu bentuk pertanggung jawaban (steadwarship) keuangan yang dibuat oleh pengelola kekayaan (pihak manajemen) kepada pihak pemilik kekayaan (pemilik perusahaan dan kreditur) dan pihak lain yang berkepentingan. Berbagai pihak yang berkepentingan dengan laporan keuangan, antara lain pemilik, kreditur/bank, investor, pemerintah, dan karyawan. Oleh karena pemakai laporan keuangan yang berbeda-beda dengan berbagai kepentingan yang berbeda, penyusunan laporan keuangan harus bersifat umum dan tidak memihak (general purpose statement).

\section{Usaha Mikro Kecil dan Menengah (UMKM)}

Sesuai dengan definisi Undang-Undang No. 9 Tahun 1995 Usaha Kecil merupakan usaha produktif dengan skala kecil. Usaha kecil memiliki kriteria kekayaan bersih paling tinggi Rp 200.000.000,00 (dua ratus juta rupiah), kekayaan Usaha Kecil ini tidak termasuk tanah dan bangunan tempat usaha. Usaha kecil memiliki hasil penjualan paling banyak $\mathrm{Rp}$ 1.000.000.000,00 (satu milyar rupiah) per tahun dan memiliki untuk memperoleh kredit dari bank maksimal di atas Rp 50.000.000,00 (lima puluh juta rupiah). Berdasarkan Undang-Undang Republik Indonesia No.9 Tahun 1995 tentang Usaha Kecil dinyatakan dalam pasal 1 bahwa : "Usaha kecil adalah kegiatan ekonomi rakyat yang berskala kecil dan memenuhi kriteria kekayaan bersih atau hasil penjualan tahunan serta kepemilikan sebagaimana diatur dalam Undang - undang ini”.

Bentuk UMKM dapat berupa perusahaan perseorangan, persekutuan, seperti misalnya firma dan CV, maupun perseroan terbatas. UMKM dapat dikategorikan menjadi tiga terutama berdasar jumlah aset dan omset sebagaimana tercantum di Undang- Undang Nomor 20 Tahun 2008 tentang UMKM sebagai berikut :

\section{Usaha Mikro}

Usaha mikro merupakan usaha produktif milik perseorangan dan atau badan usaha perseorangan yang memenuhi kriteria sebagai berikut :

1. Aset $\leq$ Rp50.000.000,00. Memiliki kekayaan bersih kurang dari atau sama dengan Rp50.000.000,00 (lima puluh juta rupiah).

2. Omset $\leq \mathrm{Rp} 300.000 .000,00$. Memiliki hasil penjualan tahunan kurang dari Rp300.000.000,00 (tiga ratus juta rupiah).

\section{Usaha Kecil}

Usaha kecil adalah usaha ekonomi produktif yang berdiri sendiri, yang dilakukan oleh orang perorangan atau badan usaha yang bukan merupakan anak perusahaan atau bukan cabang perusahaan yang dimiliki, dikuasai, atau menjadi bagian baik langsung maupun tidak langsung dari usaha menengah atau usaha besar yang memenuhi kriteria sebagai berikut :

a. Rp50.000.000,00 < Aset $\leq$ Rp500.000.000,00. Memiliki kekayaan bersih lebih dari Rp50.000.000,00 (lima puluh juta rupiah) sampai dengan paling banyak Rp500.000.000,00 (lima ratus juta rupiah) tidak termasuk tanah dan bangunan tempat usaha). 
b. $\quad$ Rp300.000.000,00< Omset $\leq 2.500 .000 .000,00$. Memiliki hasil penjualan tahunan lebih dari Rp300.000.000,00 (tiga ratus juta rupiah) sampai dengan paling banyak Rp2.500.000.000,00 (dua milyar lima ratus juta rupiah).

\section{Usaha Menengah}

Usaha ekonomi produktif yang berdiri sendiri, yang dilakukan oleh perseorangan atau badan usaha yang bukan merupakan anak perusahaan atau cabang perusahaan yang dimiliki, dikuasai, atau menjadi bagian baik langsung maupun tidak langsung dengan usaha kecil atau usaha besar yang memenuhi kriteria sebagai berikut:

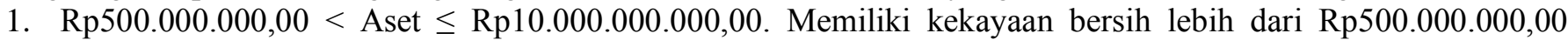
(lima ratus juta rupiah) sampai dengan paling banyak Rp10.000.000.000,00 (sepuluh milyar rupiah) tidak termasuk tanah dan bangunan tempat usaha.

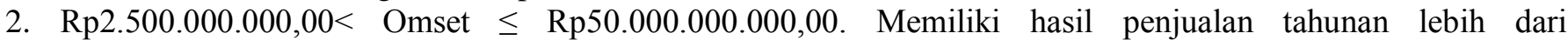
Rp2.500.000.000,00 (dua milyar lima ratus juta rupiah) sampai dengan paling banyak Rp50.000.000.000,00 (lima puluh milyar rupiah).

\section{Penelitian Terdahulu}

Penelitian yang dilakukan oleh Andrianto, dkk (2017) mengenai kajian tentang Pencatatan Akuntansi Pada Usaha Peternakan Ayam Petelur ( Studi Kasus Usaha Peternakan Ayam Petelur di Kecamatan Sugio Lamongan ) tujuan penelitian ini adalah untuk Untuk mengetahui Implementasi pencatatan akuntansi pada peternakan ayam petelur di Kecamatan Sugio Lamongan.

Ika Farida Ulfah (2017) dalam penelitian Evaluasi Sistem Pencatatan Akuntansi Pada UKM di Kabupaten Ponorogo.Tujuan dari penelitian ini adalah untuk mengetahui sistem pencatatan akuntansi yang dibuat dan diterapkan oleh para pelaku UKM Industri Batu Pecah (stone crusher) di Kabupaten Ponorogo serta untuk mengetahui apakah sistem pencatatan yang telah dilakukan dan diterapkan tersebut mampu mencerminkan kondisi ekonomi perusahaan. Penelitian serupa juga diteliti oleh Chandra Arifin, dkk (2012)yang berjudul Penerapan Akuntansi pada Usaha Mikro Kecil dan Menengah (UMKM). Tujuan dari penelitian ini adalah untuk memberikan kontribusi secara tidak langsung terhadap UMKM dengan cara memberikan informasi mengenai kendala penerapan akuntansi yang dihadapi oleh UMKM di Pertokoan khususnya di Jalan Jenderal Sudirman Salatiga kepada Pemerintah Kota dan kepada dinas terkait sehingga laporan ini dapat digunakan sebagaimana mestinya untuk meningkatkan kualitas pencatatan akuntansi untuk UMKM.

\section{METODE PENELITIAN}

Penelitian yang digunakan adalah penelitian kualitatif dengan tipe deskriptif terhadap persepsi akuntansi dan proses pencatatan akuntansi yang berlaku pada pelaku UMKM usaha keset karakter. Data yang digunakan oleh penulis dalam penelitian ini adalah data primer. Data primer dalam penelitian ini adalah berupa hasil wawancara terhadap pelaku usaha UMKM yang berada di UMKM Mr. Pelangi Semarang. Dengan pemilik sebagai sampel penelitian. Prosedur pengumpulan data dalam penelitian ini adalah berupa wawancara dan observasi.

\section{HASIL PENELITIAN DAN PEMBAHASAN}

\section{Hasil penelitian}

UMKM Mr. Pelangi beralamat di Penggaron Kidul Rt 02/Rw 04 Kelurahan Penggaron Kidul Kecamatan Pedurungan. Menurut data Dinas Koperasi dan UMKM tahun 2016 menunjukkan Kecamatan Pedurungan merupakan kecamatan dengan jumlah UMKM terbanyak. Usaha ini tergolong dalam jenis usaha konveksi karena memanfaatkan limbah-limbah kain perca dari pabrik yang kemudian diolah menjadi berbagai macam bentuk keset yang unik dan kreatif. Usaha ini dimulai pada tahun 2013, usaha ini merupakan usaha rumahan yang tergolong dalam sektor perdagangan. Sektor perdagangan merupakan salah satu sektor yang penting dalam kegiatan perekonomian dan pengaruhnya sangat kuat terhadap perkembangan dan pertumbuhan perekonomian suatu wilayah. Kontribusi sektor perdagangan terhadap PDB merupakan kontribusi yang paling besar dibanding sektor lainnya (Bank Indonesia,2015).

Berdasarkan wawancara yang dilakukan peneliti dengan pengusaha UMKM, didapatkan hasil bahwa UMKM Mr. Pelangi sama sekali tidak menerapkan pencatatan akuntansi pada usahanya. Hal ini dinyatakan dengan persepsi pengusaha UMKM bahwa pencatatan akuntansi rumit dan hanya akan menambah pekerjaan. Pelaku 
UMKM beranggapan bahwa pencatatan akuntansi harus dilakukan dengan seorang yang ahli dibidangnya karena pengusaha sekaligus pemilik UMKM tidak mempunyai pengetahuan dasar akuntansi. Dan apabila pencatatan akuntansi dilakukan oleh seorang yang sudah ahli dibidangnya, maka pemilik harus menambah karyawan dan itu mengakibatkan penambahan beban gaji karyawan. Transaksi jual dan beli yang dilakukan selama ini hanya dicatat di nota penjualan. Nota penjualan hanya mencatat transaksi tunai yang dilakukan secara langsung ditempat produksi selebihnya penjualan nontunai tidak dilakukan pencatatan pada nota penjualan. Nota penjualan juga hanya di gunakan untuk penjualan tunai sedangkan penjualan non tunai tidak ada pencatatan. Untuk menentukan laba usaha, pemilik hanya mencatat pendapatan yang diperoleh serta beban yang dikeluarkan, maka akan diketahui berapa laba yang di dapatkan. Berikut adalah tabel pendapatan Mr. Pelangi Semarang :

\section{Tabel 1. Pendapatan Mr. Pelangi Semarang}

\begin{tabular}{llll}
\hline Tgl/Bln/Thn & Keterangan & Penerimaan & Pengeluaran \\
\hline $10 / 10 / 17$ & $\begin{array}{l}\text { Diterima Dari Penjualan Keset 10 } \\
\text { Buah @ Rp 60.000 }\end{array}$ & Rp 600.000,00 & - \\
\hline & $\begin{array}{l}\text { Dikeluarkan Untuk Membeli Bahan } \\
\text { Baku }\end{array}$ & - & Rp 310.000,00 \\
\hline & Sisa Surplus (Deficit) & Rp 290.000,00 \\
\hline
\end{tabular}

Sumber : Data Diolah Oleh Peneliti

Berdasarkan hasil observasi langsung di lapangan, ada beberapa alasan yang mungkin perlu diperhatikan yang menyebabkan tidak adanya penyusunan laporan keuangan oleh pelaku UMKM sehingga menyebabkan kemampuan menyusun laporan keuangan tidak berpengaruh terhadap kinerja usaha mereka disebabkan karena pelaku UMKM :

1. Lebih mengutamakan pengalaman meningkatkan kinerja usahanya dibandingkan membuaat laporan akuntansi sebagai bukti kinerja usahanya.

2. Sulit menyisihkan waktu untuk membuat pencatatan akuntansi karena pelaku UMKM sering merangkap tugas dalam menjalankan usahanya dan merasa laporan keuangan itu rumit.

3. Kurang memperhatikan pengelolaan akuntansi karena menurut pelaku UMKM dampaknya tidak terlihat secara jelas atau tidak berpengaruh langsung terhadap kelangsungan usahanya.

4. Pelaku UMKM beranggapan bahwa usaha yang dijalankan tidak begitu besar maka tidak diperlukan pencatatan akuntansi.

5. Kurangnya pengetahuan atau keterampilan pelaku UMKM yang berhubungan dengan pencatatan akuntansi.

6. Tidak adanya tenga ahli dibidang akuntansi khususnya pencatatan laporan keuangan.

7. Dana yang digunakan untuk usaha sering bercampur dengan dana sendiri atau langsung digunakan untuk membeli barang tanpa melakukan pencatatan akuntansi pada laporan keuangan terlebih dahulu.

\section{Pembahasan}

Dengan akuntansi yang memadai maka pelaku UMKM dapat memenuhi persyaratan pemodalan dari pihak eksternal seperti Bank. Namun dalam pelaksanaannya pembukuan tersebut merupakan hal yang sulit bagi pengusaha UMKM karena keterbatasan pengetahuan terhadap ilmu akuntansi, rumitnya proses akuntansi serta anggapan bahwa laporan keuangan bukanlah hal yang penting bagi pelaku UMKM. Berdasarkan hasil penelitian adanya kesenjangan antara standar akuntansi yang ditetapkan pemerintah dan persyaratan kredit dari bank dengan pencatatan akuntansi pada UMKM.

Berdasarkan hasil observasi dan wawancara yang dilakukan, dapat ditemukan beberapa faktor-faktor yang mempengaruhi belum dilakukannya pencatatan akuntansi pada UMKM Mr. Pelangi, yaitu :

1. Tidak mengetahui bagaimana pencatatan akuntansi yang benar. Sesuai dengan hasil observasi dan wawancara, bahwa pemilik tidak mengetahui bagaimana pencatatan akuntansi khususnya laporan keuangan yang baik dan benar, sehingga pemilik tidak menerapkan pencatatan akuntansi sesuai standar akuntansi keuangan. 
2. Belum bisa membuat laporan keuangan, selain tidak mengetahui bagaimana pencatatan akuntansi atau laporan keuangan, pemilik juga tidak bisa membuat laporan keuangan. Kurangnya pengetahuan akuntansi yang baik, membuat pemilik tidak bisa menerapkan pencatatan akuntansi pada usahanya.

3. Pemilik belum mengetahui manfaat dari pencatatan akuntansi. Kurangnya pengetahuan pemilik akan manfaat dari pencatatan akuntansi, menjadi salah satu faktor yang menyebabkan pemilik tidak melakukan pencatatan akuntansi atau membuat laporan keuangan.

4. Tidak memiliki pegawai yang ahli dalam pencatatan akuntansi. Pemilik beranggapan bahwa pencatatan akuntansi yang baik dan benar harus dilakukan oleh ahlinya, sedangkan untuk memiliki pegawai yang bertanggung jawab sebagai pengelola keuangan di usaha miliknya pemilik harus memberikan upah sehingga menambah biaya dalam usaha.

Apabila UMKM telah melakukan pencatatan akuntansi secara relevan, akurat dan handal pastinya akan mempermudah dalam proses pengajuan pinjaman ke pihak perbankan. Untuk terciptanya sektor UMKM dengan pengelolaan keuangan yang baik, profesional dan berdaya saing, maka diperlukan unsur "keharusan" dalam pencatatan dan pelaporan keuangan. unsur "keharusan" ini diantaranya dapat dilaksanakan dalam bentuk persyaratan yang harus dipenuhi oleh UMKM guna memperoleh pembiayaan. Disinilah diperlukan adanya dukungan dan perhatian dalam bentuk pengawasan (controlling) dan pendampingan terhadap penerapan pencatatan akuntansi pada UMKM.

\section{Kesimpulan}

\section{PENUTUP}

Berdasarkan hasil analisis data dan pembahasan makasimpulan yang dapat diambil dari penelitian ini adalah tidak adanya pencatatan akuntatansi pada Usaha Mikro Kecil Menengah Mr. Pelangi Semarang. Catatan yang dibuat masih sangat sederhana, yaitu hanya terkait dengan pembelian bahan baku serta sebagian biaya yang mereka keluarkan saja. Sehingga sangat sulit untuk mengetahui seberapa besar biaya keseluruhan yang dibutuhkan dalam sekali produksi, dan menentukan laba usaha. Hal ini menunjukkan bahwa pengusaha UMKM belum menerapkan pencatatan akuntansi yang baik dan memadai. Hasil pencatatan yang baik akan dapat digunakan sebagai dasar dalam pengambilan keputusan serta pengajuan kredit pada bank untuk mendapatkan penambahan modal.

\section{Saran}

Pencatatan akuntansi pada kenyataannya masih menjadi hal yang sulit untuk Usaha Mikro Kecil dan Menengah (UMKM). Oleh karena itu saran dari penelitian ini adalah :

1. UMKM sebaiknya melakukan pencatatan akuntansi untuk mempermudah mendapatkan modal dari pihak kreditur serta sebagai dasar pengambilan keputusan serta memaksimalkan laba yang ingin diperoleh.

2. Diharapkan semakin sering diadakan pertemuan antar pengusaha UMKM, dimana dalam perkumpulan tersebut membahas mengenai pencatatan akuntansi yang baik daan benar yang dapat menunjang keberhasilan UMKM dalam mengembangkan usahanya.

3. Adanya peran pemerintah dalam pengawasan dan pendampingan pencatatan akuntansi sehingga adanya kesadaran pelaku UMKM untuk melakukan pencatatan akuntansi.

\section{Rekomendasi}

Terkait penelitian yang telah dilakukan perlu adanya tindak lanjut dari hasil penelitian, maka dari itu untuk penelitian selanjutnya diharapkan :

1. Adanya penelitian ulang tentang pencatatan akuntansi pada usaha lainnya yang tergolong dalam entitas tanpa akuntabilitas publik.

2. Menambah informan agar konsep triangulasi terpenuhi dan hasil penelitian jauh lebih kredibel. 


\section{DAFTAR PUSTAKA}

Andrianto, dkk,. 2017. Pencatatan Akuntansi pada Usaha Peternakan Ayam Petelur (Studi Kasus Usaha Peternakan Ayam Petelur di Kecamatan Sugio Lamongan). Majalah Ekonomi. Vol XXII, No 01. Juli 2017. ISSN: 14119501.

Anonim. 2017. http : // www.yuanbigie.com/2017/11/pengertian-pengakuan-pengukuran.html diakses pada tanggal 21 November 2017.

Arifin, Chandra, dkk,. 2012. Penerapan Akuntansi pada Usaha Mikro Kecil dan Menengah (UMKM). JMK, Vol. 10, No. 2

Atmadja, A. T,. dkk,. 2014,. Analisis Penerapan Pencatatan Keuangan Berbasis SAK ETAP pada Usaha Mikro Kecil Menengah (UMKM) (Sebuah Studi Intrepetatif pada Peggy Salon),. Vol. 2, No. 1, Tahun 2014.

Bank Indonesia. 2015. Profil bisnis Usaha Mikro Kecil dan Menengah (UMKM) dan Usaha Besar (UB). Tersedia di (http://www.bi.go.id/ diakses tanggal 21 Januari 2018)

Cahyati, A. D,. dkk,. 2011. Pemahaman dan Kesiapan UKM dalam Implementasi SAK ETAP: Survey pada UKM di Bekasi,. JRAK, Vol. 2, No. 2, Agustus 2011.

Damayanti, Theresia Woro,. dan Yohanes H. A,. 2017. Niat Melakukan Pencatatan Akuntansi pada Usaha Kecil Menengah: Pengetahuan Akuntansi Ataukah Herding?. Jurnal Ekonomi dan Bisnis, Vol. 20, No. 2, Oktober 2017.

Dinas Koperasi dan UMKM Provinsi Jawa Tengah. Penyerapan Tenaga Kerja UMKM Binaan Provinsi Jawa Tengah. Diakses pada tanggal 22 Desember 2017 dari http: //dinkop-umkm.jatengprov.go.id

Kurniawansyah, Deddy. 2016,. Penerapan Pencatatan Akuntansi dan Penyusunan Laporan Keuangan Berdasarkan SAK ETAP pada UMKM Desa Gembongsari,. ISBN 978-602-60569-2-4,. 17 Desember 2016.

Liputan6.com. (2014, September 17). Produk Umkm Semarang Berkualitas tapi tak dikenal. Diakses pada tanggal 3 Januari 2017, dari bisnis.liputan6.com.

Nurlaela, Siti,. 2015. Kemampuan Menyusun Laporan Keuangan Usaha Kecil Menengah Pengaruhnya Terhadap Kinerja UKM Kerajinan Gitar di Kabupaten Sukoharjo. Jurnal Paradigma, Vol. 12, No. 02, Agustus 2014Januari 2015

Purhantara, Wahyu. 2010. Metode Penelitian Kualitatif untuk Bisnis. Yogyakarta: Graha Ilmu.

Puspitaningrum, Titis, dkk,. 2017. Pelaporan Keuangan pada UMKM di Surabaya (Studi pada UKM Diah Cookies). Jurnal Ilmiah Akuntansi dan Bisnis, Vol 2, No 01. 2017.

Suartana, I Wayan. 2010. Akuntansi Keperilakuan. Yogyakarta: Andi Offset.

Sugiyono. 2009. Metode Penelitian Kuantitatif, Kualitatif dan R\&D. Bandung: Alfabeta.

Sugiyono. 2014. Metode Penelitian Bisnis. Bandung: Alfabeta

Ulfah, Ika Farida,. 2017. Evaluasi Sistem Pencatatan Akuntansi pada UKM di Kabupaten Ponorogo. Cendekia Akuntansi, Vol. 5, No. 02, Mei 2017 
Undang-Undang Republik Indonesia. 2008. Nomor 20 Tahun 2008 Tentang Usaha Mikro Kecil dan Menengah (http://www.bi.go.id/i/tentangbi/uubi/Documents/UU20Tahun2008UMKM.pdf, diakses tanggal 20 Desember 2017.

Tulung, Joy Elly., and Ramdani, Dendi .2016. The Influence of Top Management Team Characteristics on BPD Performance. International Research Journal of Business Studies, Volume 8 Nomor 3, 155-166.

Tulung, Joy Elly., and Dendi Ramdani. 2018. Independence, Size and Performance of the Board: An Emerging Market Research. Corporate Ownership \& Control, Volume 15, Issue 2, Winter 2018. $\underline{\mathrm{h}}$

Wibowo, Alex,. dan E. P. Kurniawati,. 2015,. Pengaruh penggunaan Informasi akuntansi Terhadap Keberhasilan Usaha Kecil Menengah (Studi pada Sentra Konveksi di Kecamatan Tingkir Kota Salatiga),. Jurnal Ekonomi dan Bisnis, Vol. XVIII, No. 2, Agustus 2015.

Wind, Ajeng. 2015. Buku Saku Akuntansi. Jakarta: Laskar Aksara.

Ikatan Akuntan Indonesia. 2012. Standar Akuntansi Keuangan. Jakarta : Salemba Empat. 